Research Article

\title{
Development of "Child Friendly ICT" Textbooks to Improve Professional Competence of Teacher Candidates: A Case Study of Early Childhood Education Program Students
}

\author{
Sri SUMARNI ${ }^{1}$, Rahmi RAMADHANI ${ }^{2}$, Yoppy SAZAKI ${ }^{3}$, Ruri Tria \\ ASTIKA $^{4}$, Windi Dwi ANDIKA ${ }^{5}$, Andika Eko PRASETIYO ${ }^{6}$
}

Received: 24 July 2019 Accepted: 30 August 2019

\begin{abstract}
The purpose of this study is to develop child friendly textbooks of Information, Communication, \& Technology (ICT) that are valid, practical and effective in improving the professional competence of students in teacher early childhood education program, Sriwijaya University. This study uses the R\&D research model with the type of ADDIE model which consists of five stages, namely analysis, design, develop, implementation, and evaluation. The sample in this study was students in early childhood teacher education program. In the implementation phase, field trials were carried out as a result of the development of child-friendly ICT-based teaching books with a sample of 42 people consisting of 12 samples for the small group test and 30 samples for the large group test. Based on the test results of data analysis, it was found that the "child-friendly ICT" textbook that had been developed was valid, practical and effective. The results obtained prove that childfriendly ICT textbooks contribute to improving the professional competence of students. Child-friendly ICT textbooks not only provide new understanding and knowledge of ICT use in child-friendly learning, but also enhance the skills of prospective teachers in using ICT-based teaching materials.
\end{abstract}

\section{Keywords}

teaching materials, information, communication, \& technology (ICT), child friendly, professional competence, prospective teacher students

\section{To cite this article:}

Sumarni, S., Ramadhani, R., Sazaki, Y., Astika, R, T., Andika, W. D., \& Prasetiyo, A.E. (2019). Development of "Child Friendly ICT" Textbooks to Improve Professional Competence of Teacher Candidates: A Case Study of Early Childhood Education Program Students. Journal for the Education of Gifted Young Scientists, 7(3), 643-658. DOI: http://dx.doi.org/10.17478/jegys.596095

\footnotetext{
Department of Early Childhood Education, Universitas Sriwijaya, Palembang, Indonesia. sri_sumarni@fkip.unsri.ac.id

${ }^{2}$ Universitas Potensi Utama, Medan, Indonesia.rahmiramadhani3@gmail.com

${ }^{3}$ Informatic Management, Universitas Sriwijaya, Indonesia.yoppysazaki@gmail.com

${ }^{4}$ Pascasarjana Universitas Negeri Jakarta, Jakarta, Indonesia.ruritriaastika@yahoo.com

Department of Early Childhood Education, Universitas Sriwijaya, Palembang, Indonesia. dwiandika892014@gmail.com

6 Graduate school of humanities and social sciences, University of Melbourne, Parkville Victoria, Australia.andikaekop@gmail.com
} 


\section{Introduction}

The last decade of Information Communication and Technology (ICT) has developed enough messages in various branches of science, both in the fields of business(Kasayanond, Umam, \& Jermsittiparsert, 2019), industry(Rufaidah, AtIrsyadi, Saregar, \& Umam, 2018), community life to education. The issue of ICT has received considerable critical attention in the world of education (Deb Roy, 2015; Simin Ghavifekr, Afshari, \& Salleh, 2012). The application of ICT in learning provides a dynamic, including in the learning process(Hartinah, Sholikhakh, et al., 2019). ICT not only has an effect on the relationship between students and teachers, but also provides an increase in the value of the learning system itself(Abdurrahman, Saregar, \& Umam, 2018). Through the use of technology as part of ICT, it can increase the learning process to be more efficient, effective as well as providing competency skills, but also to students (Ramadhani, Umam, Abdurrahman, \& Syazali, 2019). The link between technologies in increasing competence can be seen in Figure 1.

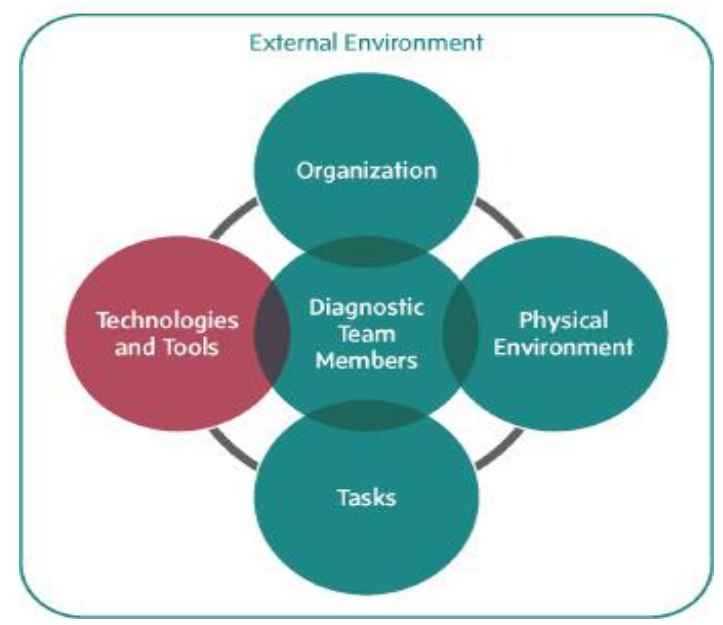

\section{Figure 1}

The Relationship Between Technology and Other Competencies in Education

Technology integration in education refers to the use of computer-based communication used in the learning process. In connection with ICT-based learning in the current digital era, teachers are seen as creators in using ICT in the learning process in the classroom (S Ghavifekr \& Rosdy, 2015). ICT in the learning process allows to include both hardware and software such as audio, data (high and low speed), video, internet, computers to software (Widayanti, Abdurrahman, \& Suyatna, 2019; Mostafa, Hashemi, Sosahabi, \& Berahman, 2017; Peter Kayode, Bukola Olaronke, \& Kayode, 2014). The development of technology penetrated all 
segments of education, one of which was education for early childhood. Playing while learning is the essence of play that animates every early childhood learning activity(Lestari et al., 2019). By playing, the child interacts with the object and consciously and unconsciously learns the object's attributes, and this has been explained by Piaget that learning with real objects is very important for early childhood(Andini \& Yunianta, 2018). However, in addition to real objects, there are other media that can be used to transform knowledge and abilities in early childhood, namely integrating learning objects with technology(Sagala, Umam, Thahir, Saregar, \& Wardani, 2019).

However, the facts in the field of the use of technology-based learning objects in early childhood education are still rarely applied. Researchers conducted observations and surveys at several early childhood education schools spread in the city of Palembang, South Sumatra, Indonesia. Based on observations and surveys conducted, it was found that there are only a few early childhood education schools that have implemented technology-based learning. The technology-based learning object used is only limited to the use of projectors and power points or animated videos that are displayed using a laptop(Diani, Herliantari, Irwandani, Saregar, \& Umam, 2019). The use of these objects is still fully used by the teacher and there is no interaction of students in using the learning object. The learning object used is also still not friendly to children, especially the use of the Youtube application in the learning process in early childhood schools(Hartinah, Suharso, et al., 2019). The tendency of children to see animated videos through YouTube pages makes children uncontrolled and become addicted(Syahrir et al., 2018), and the use of these learning objects must also be completely under the guidance of the teacher entirely(Maulidi, Apriliani, \& Syazali, 2019). The technology-based learning object should be developed by the teacher himself. It aims to enable teachers to develop learning objects based on student characteristics and learning themes that are being carried out(Maskur, Syazali, \& Utami, 2019). The development of technology-based learning objects can also be controlled for their use and friendly to students in early childhood schools(Habibi et al., 2019). Learning objects that are developed can also be applied together, not only used by the teacher, but also can be used by students themselves.

Development of a learning object that is also part of learning material integrated with technology should be designed according to children's development and more specific goals. Technology-based learning provides an opportunity for early childhood to explore more about the elements of color, music to caricatures that children love(Kusumawati \& Nayazik, 2018). This provides an opportunity for early age students to increase students' interests and abilities to avoid them from feeling boredom that often arises and able to foster high-level thinking skills(Abdurrahman, Nurulsari, Maulina, \& Ariyani, 2019; Nisa, 2012). 
The use of technology in the distribution of early childhood is very good and has a positive impact on the development of both cognitive, psychomotor and affective aspects of students(Diani, Irwandani, et al., 2019). To succeed in using technology in learning in the classroom, teacher education programs must provide a special curriculum. Teacher candidates must be prepared to be able to understand various types of media technology(Muhamad Syazali et al., 2019), procedures and steps on how to develop and provide ICT technology-based learning that can improve children's abilities to be friendly to early childhood(M. Syazali et al., 2019). In addition, prospective teachers can also improve their professional skills as teachers in managing learning in the classroom to be more effective and efficient through technology integration (Vrasidas \& Nicosia, 2001). The importance of understanding technology in learning for teachers is supported by research conducted by DarlingHammond and colleagues in 2009 stating that increasing student competency is closely related to the type of teaching carried out by teachers who must understand pedagogy, what content to study and what technology the right to use(Komala Sari, Syazali, \& Farida, 2016). This results in the professional competence of a prospective teacher can develop. In a national survey conducted by Darling-Hammond and colleagues, it was also found that $59 \%$ of teachers who have good professional competence will provide good learning experiences for students to have an impact on the learning outcomes that students get (Ehsanipour \& Gomez Zaccarelli, 2017). This is also supported by several previous studies that have reported that ICT that is integrated with the learning curriculum is proven to have a good impact on the ability of students to absorb learning material starting from the cognitive, psychomotor, affective, and creative thinking aspects (Khoiriah, Jalmo, \& Abdurrahman, 2016). In addition, the application of technology in learning has a significant relationship to the teaching ability of prospective teachers. ICT technology-based learning also provides experience to improve the professional skills of prospective teachers who can be useful after they finish their studies in teacher education study programs for early childhood (Aoki, 2010; Aslan \& Zhu, 2015; Relmasira \& Thrupp, 2016). Seeing the importance of technology integration in learning (Putra, Nur Kholifah, Subali, \& Rusilowati, 2018), especially for early childhood category students, researchers want to develop teaching materials titled child-friendly ICT as a guide for prospective teacher students to use technology in the learning process in the classroom. 


\section{Method}

\section{Research Design}

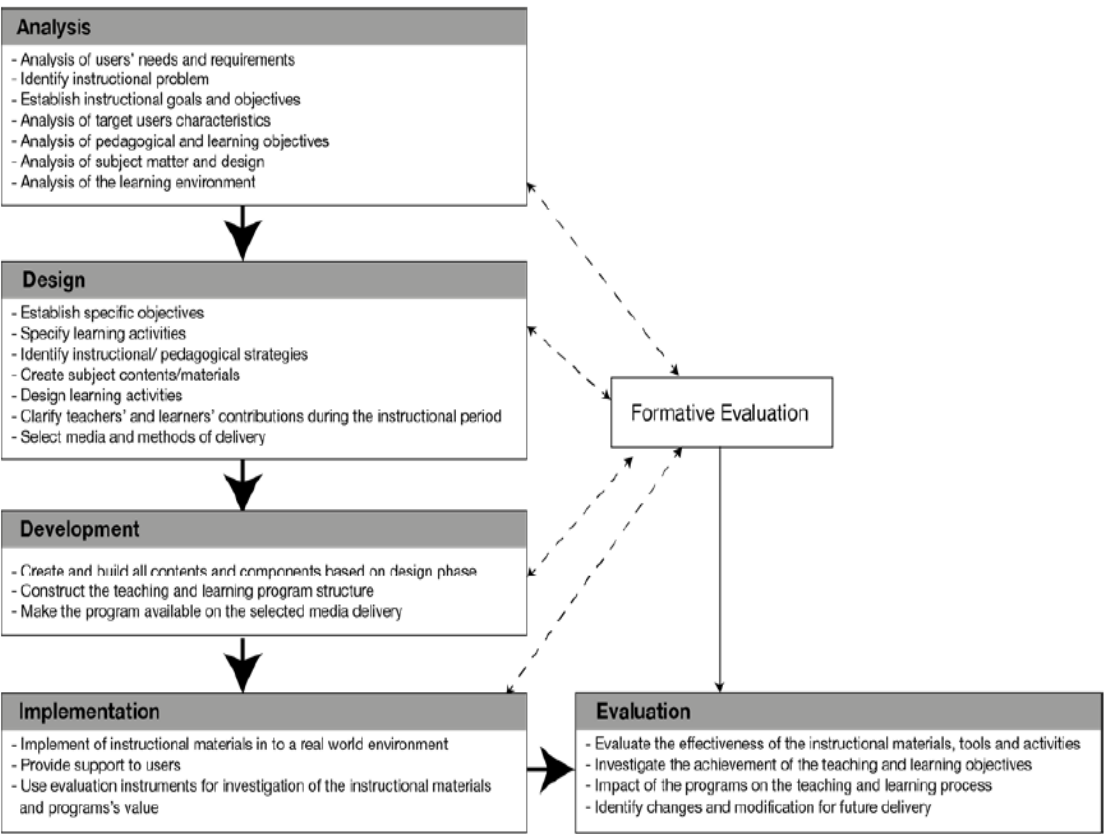

\section{Figure 2}

Stage of Analysis, Design, Development, Implementation, and Evaluation (ADDIE) Teaching Design Model

In previous studies it has been reported that, the analysis phase in the design of the ADDIE teaching model gives more attention to the characteristics of learners than at other stages, because students are the main element in learning (Ozdilek \& Robeck, 2009). A big advantage of the development stage in the design of the ADDIE teaching model is that it systematically describes a well-organized process in helping the designer (educator) during the development process (Samsudin, Suhandi, Rusdiana, Kaniawati, \& Coştu, 2016). The latest evidence shows (Figure 2) that each ADDIE stage is interconnected and interacts with each other (Aldoobie, 2015).

\section{Participants}

Participants in this study were prospective teacher students at the Early Childhood Education Study Program, Sriwijaya University. Participants in this study were divided into two groups, namely a small group consisting of 12 prospective student teachers and a large group of 30 prospective teacher students. The total number of participants in this study were 42 prospective teacher students. The two groups of participants will be taught using the "child-friendly ICT" textbook that has been developed using the ADDIE teaching design model. This study focused on the implementation of the results of the development of the "child-friendly ICT" root 
book. Stages of analysis, design and development have been done before. In the implementation phase there will be a formative evaluation consisting of a pre-test and post-test which aims to see whether prospective student students have a theoretical understanding of the application of ICT in the learning outlined in the 'child-friendly ICT' textbook that has been developed previously. The results of the formative evaluation (pre-test and post-test) will be analyzed with the aim of seeing whether there is an increase in the professional ability of prospective students of early childhood education study programs after being taught using "ICT-friendly" textbooks.

\section{Data Collection}

Data on the results of small groups and large groups at the implementation stage are collected formative evaluation results that have been carried out on each group of participants. Formative evaluation is done in two parts, namely the pre-test and posttest. After taking the pre-test data collection, the next step is the provision of learning using "child-friendly ICT" textbooks, and ending with giving post-tests. The pre-test and post-test conducted consisted of 8 multiple choice questions which were divided into easy, medium and difficult questions. In addition to the results of the pre-test and post-test, research data collection was also conducted using questionnaires aimed at looking at the effectiveness and practicality of the use of "child-friendly ICT" textbooks that had been developed. Previously, "child-friendly ICT" textbooks were validated by experts in the field of teaching material development and the results were obtained that "child-friendly ICT" textbooks were valid and feasible to be used in the implementation phase. Validation of "ICT-friendly" textbooks was carried out at the development stage in the design of the ADDIE teaching model, because this model is very effective for developing student achievement.

\section{Results and Discussion}

After the data obtained from the formative evaluation of prospective teacher students, it was found that the increase in student test results in small groups was higher than the results of the large group test. Different results were obtained that the spread of data in large groups was more diffuse than data in small groups. The average results of the pre-test and post-test in the two groups of participants taught using "ICT-friendly" textbooks can be seen in Table 1 below: 


\section{Table 1.}

Results of Calculation of Pre-Test and Post-Test on Both Participant Groups

\begin{tabular}{lcccccc}
\hline \multicolumn{7}{c}{ Descriptive Statistics } \\
\hline & N & Minimum & Maximum & Mean & $\begin{array}{c}\text { Std. } \\
\text { Deviation }\end{array}$ & Variance \\
\hline Pre_Test_Experiment & 12 & 49.00 & 67.00 & 57.00 & 5.592 & 31.273 \\
Post_Test_Experiment & 12 & 84.00 & 95.00 & 88.17 & 3.762 & 14.152 \\
Pre_Test_Control & 30 & 49.00 & 67.00 & 56.57 & 5.117 & 26.185 \\
Post_Test_Control & 30 & 80.00 & 95.00 & 86.90 & 3.717 & 13.817 \\
\hline
\end{tabular}

Based on Table 1 above, it can be seen that the average pre-test in the small group was higher (57.00) than the average pre-test in the large group (56.57). The average post-test in the small group (88.17) was also higher than the post-test average in the large group (86.90). The same thing is also seen in the results of the standard deviation both at the pre-test average and the post-test average of the small group is higher than the large group. This means that the test results data (both pre-test and post-test) in the small group are more diffuse and different than the test results in the large group. The results of differences in the average test in both groups of participants can also be seen in the graph (Figure 3).

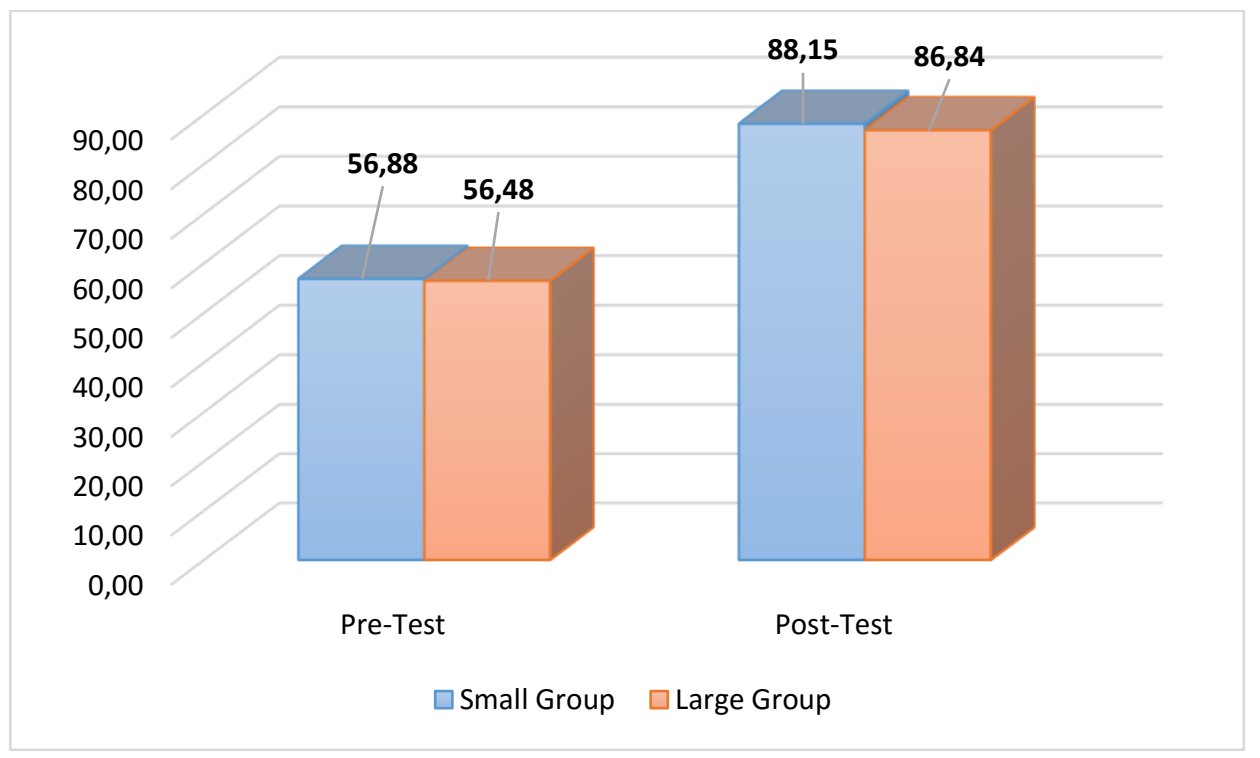

\section{Figure 3.}

Differences in Pre-Test and Post-Test in Both Participant Groups

The results of the calculation of the average increase (N-Gain) of the test results in the two groups of participants can be seen in Table 2 below: 
Table 2.

N-Gain Calculation Results for the Two Participant Groups

\begin{tabular}{ccccccc}
\hline \multicolumn{7}{c}{ Descriptive Statistics } \\
\hline & N & Minimum & Maximum & Mean & Deviation & Variance \\
\hline NGain_Experiment_Class & 12 & .55 & .89 & .7225 & .10146 & .010 \\
NGain_Control_Class & 30 & .47 & .89 & .6923 & .10078 & .010 \\
\hline
\end{tabular}

Based on the results of calculations in Table 2 above, the results showed that the average increase (N-Gain) test results in the small group (0.7225) were higher than the average increase (N-Gain) test results in the large group (0.6923). Before testing the hypothesis whether the use of "child-friendly ICT" textbooks provides a significant increase in the test results of prospective teacher students, analysis of data normality and analysis of data homogeneity is carried out as one of the parametric inferential statistical requirements. The group N-Gain data is tested for data normality and the homogeneity test of data can be seen in Table 3 and Table 4 below:

Table 3.

Calculation Results N-Gain Data Normality Test for Participant Groups

\begin{tabular}{lc|c|c|c|c|c}
\hline \multicolumn{1}{c}{ Tests of Normality } \\
\hline & Kolmogorov-Smirnov & \multicolumn{3}{c}{ Shapiro-Wilk } \\
\cline { 2 - 8 } & Statistic & df & Sig. & Statistic & df & Sig. \\
\hline N_Gain_Small_Group & .144 & 12 & $.200^{*}$ & .977 & 12 & .966 \\
\hline N_Gain_Large_Group & .172 & 12 & $.200^{*}$ & .959 & 12 & .767 \\
\hline *. This is a lower bound of the true significance. \\
a. Lilliefors Significance Correction
\end{tabular}

\section{Table 4.}

Results of Calculation of N-Gain Data Homogeneity Test on Participant Groups

\section{Test of Homogeneity of Variances}

\begin{tabular}{llc|c|c|c}
\hline \multirow{2}{*}{\begin{tabular}{c} 
N_Gain \\
\multirow{2}{*}{ Total }
\end{tabular}} & $\begin{array}{c}\text { Levene } \\
\text { Statistic }\end{array}$ & df1 & df2 & Sig. \\
\cline { 2 - 6 } & Based on Mean & .048 & 1 & 40 & .828 \\
\cline { 2 - 6 } & $\begin{array}{l}\text { Based on Median } \\
\text { Based on Median and } \\
\text { with adjusted df }\end{array}$ & .067 & 1 & 40 & .797 \\
\cline { 2 - 6 } & Based on trimmed mean & .050 & 1 & 39.309 & .797 \\
\hline
\end{tabular}

Based on the calculation of the normality test in Table 3, it was found that the NGain data of the participant group obtained the same significant value of 0.200 . The 
significance value obtained is greater than $0.05 p$ value $(0.200>0.05)$. This shows that the N-Gain data of the group of participants is normally distributed. Likewise with the homogeneity test calculation shown in Table 4 above. The results of the above homogeneity calculation show that the significance value Based on Mean is 0.828 and is greater than $p$ value $0.05(0.828>0.05)$. This shows that the group's N-Gain data is homogeneous.

The N-Gain data is in accordance with the calculations in Table 3 and Table 4 above shows that the data are normally distributed and homogeneous. This is in accordance with the parametric hypothesis test conditions, where the research data must be normally distributed and homogeneous. To see whether there is a significant increase in the use of "child-friendly ICT" textbooks for prospective teacher students, hypothesis testing is done using the Independent Sample T-Test. The results of the calculation of hypothesis testing using the SPSS 25.00 statistical tool can be seen in Table 5 below:

\section{Table 5.}

Results of Independent Sample T-Test Hypothesis Test Calculation

\begin{tabular}{|c|c|c|c|c|c|c|c|c|c|c|}
\hline \multicolumn{11}{|c|}{ Independent Samples Test } \\
\hline & & \multirow{3}{*}{\multicolumn{2}{|c|}{$\begin{array}{c}\text { Levene's } \\
\text { Test for } \\
\text { Equality of } \\
\text { Variances } \\
\end{array}$}} & \multirow{3}{*}{\multicolumn{7}{|c|}{ t-test for Equality of Means }} \\
\hline & & & & & & & & & & \\
\hline & & & & & & & & & & \\
\hline & & \multirow{5}{*}{$\mathrm{F}$} & \multirow{5}{*}{ Sig. } & \multirow{5}{*}{$\mathrm{t}$} & \multirow{5}{*}{ df } & \multirow{5}{*}{$\begin{array}{c}\text { Sig. } \\
(2- \\
\text { tailed) }\end{array}$} & \multirow{5}{*}{$\begin{array}{c}\text { Mean } \\
\text { Differe } \\
\text { nce }\end{array}$} & \multirow{5}{*}{$\begin{array}{l}\text { Std. } \\
\text { Error } \\
\text { Differ } \\
\text { ence }\end{array}$} & \multirow{4}{*}{\multicolumn{2}{|c|}{$\begin{array}{c}95 \% \\
\text { Confidence } \\
\text { Interval of the } \\
\text { Difference }\end{array}$}} \\
\hline & & & & & & & & & & \\
\hline & & & & & & & & & & \\
\hline & & & & & & & & & & \\
\hline & & & & & & & & & Lower & Upper \\
\hline \multirow{6}{*}{$\begin{array}{c}\text { N_Gain } \\
\text { _Total }\end{array}$} & $\begin{array}{l}\text { Equal } \\
\text { variances }\end{array}$ & \multirow{2}{*}{.048} & \multirow{2}{*}{.828} & \multirow{2}{*}{.875} & \multirow{2}{*}{40} & \multirow{2}{*}{.387} & \multirow{2}{*}{.03017} & \multirow{2}{*}{.0344} & \multirow{2}{*}{-.0395} & \multirow{2}{*}{.0998} \\
\hline & assumed & & & & & & & & & \\
\hline & \multicolumn{2}{|l|}{ Equal } & & \multirow{4}{*}{.872} & \multirow{4}{*}{20.2} & \multirow{4}{*}{.393} & \multirow{4}{*}{.03017} & \multirow{4}{*}{.0345} & \multirow{4}{*}{-.0419} & \multirow{4}{*}{.1022} \\
\hline & variances & & & & & & & & & \\
\hline & not & & & & & & & & & \\
\hline & assumed & & & & & & & & & \\
\hline
\end{tabular}

Based on the calculations in Table 6 above, it was found that the significance value of the N-Gain value using the "ICT-friendly child" textbook was 0.387 (equal variance assumed). The significance value obtained is greater than the $\mathrm{p}$ value of 0.05 which is $0.387>0.05$. This proves that there are differences in the average increase in the test results that are significant for the two groups of participants who are taught using "ICT-friendly" textbooks. The results obtained showed that the number of participants did not affect the quality of learning to increase the average test results 
in the group of participants. The effect of "child-friendly ICT" textbooks has a large effect on increasing the average group test of participants. This also proves that the use of "child-friendly ICT" textbooks that have been developed by effective research teams to be used more widely for prospective students of the Sriwijaya University early childhood education program and proven to be able to improve the professional competence of prospective teacher students based on test results obtained.

To see whether "child-friendly ICT" textbooks are also practical to be used more widely in learning for prospective teacher students, a questionnaire was collected. The questionnaire contains statements that assess whether teaching materials used are in accordance with the needs of prospective teacher students. The number of statements in the questionnaire as many as 15 pieces and the results of the questionnaire calculation can be seen in the graph Figure 4:

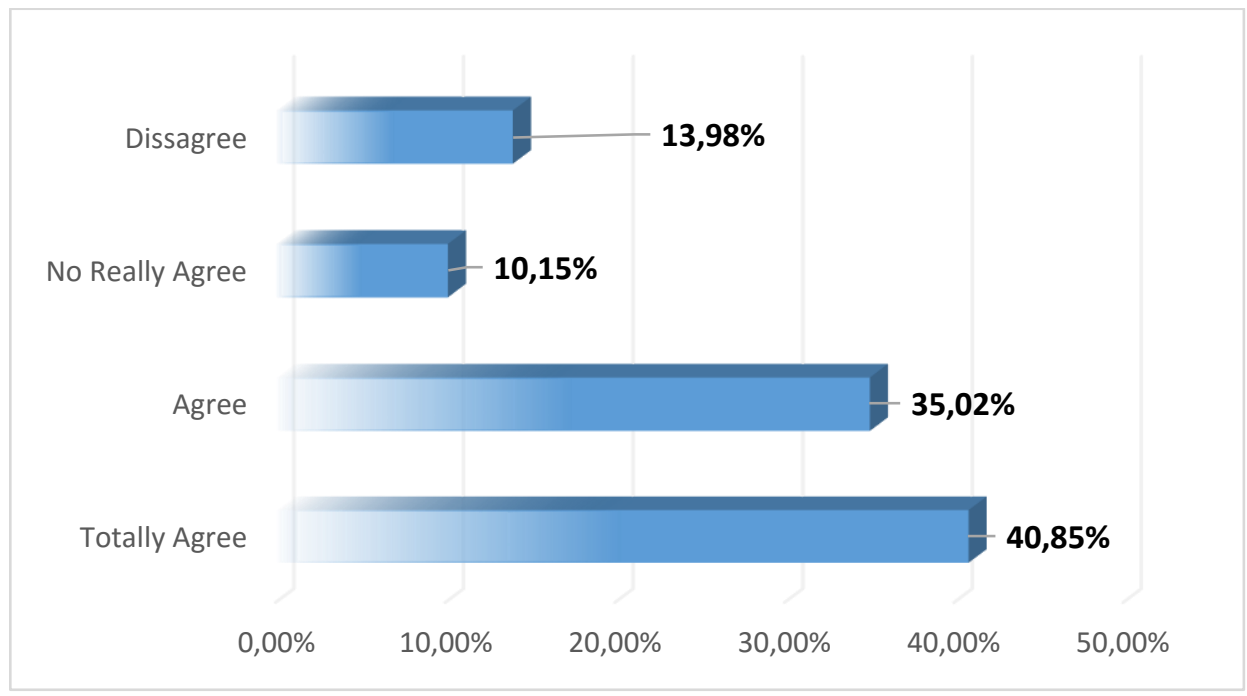

\section{Figure 4.}

Calculation of Chart Questionnaire Use of "ICT Child Friendly" Textbooks in Learning

The results seen in Figure 4 above, indicate that there are $75.87 \%$ of prospective teacher students who give a very agree and agree to the use of "child-friendly ICT" textbooks in improving their professional competence. Whereas as many as $24.13 \%$ of prospective teacher students who gave an assessment disagree and disagree with the use of "ICT-friendly" textbooks in learning. Based on the results of interviews with the prospective teacher students who fall into the category of lack and disagree with the use of "child-friendly ICT" textbooks stated that, they not only need theory in applying technology in the learning process, but also require real practice how 
technology integration friendly to children in the learning process for early childhood.

Some literature has emphasized the importance of ensuring a reliable assessment of the level of ability and skills of PAUD teachers in technology (ICT) as the professional competence that they will have (Vitanova, Atanasova-Pachemska, Iliev, \& Pachemska, 2015). The latest evidence shows that teachers must be equipped with the ability to use technology (ICT), because all literacy will gradually follow the development of an increasingly evolving era of digital literacy (Kirti., Mann, \& Gupta, 2014), where the need to incorporate ICT into the learning curriculum for prospective teachers (Xiong \& Lim, 2015). A number of authors have considered the effects of early childhood education teacher education, PAUD teacher candidates who need ICT competence so that teachers can provide ICT stimulation that is appropriate for early childhood to develop optimally (Drigas, Kokkalia, \& Lytras, 2015; Kirti. et al., 2014; Lecluijze, Penders, Feron, \& Horstman, 2015; Mertala, 2017).

There are a number of things that are important to note by teachers in teaching ICT in early childhood, so that ICT becomes child-friendly. The researcher sets out different ways in which the screen time or time to watch the gadget must be carefully arranged (Muhamad Syazali, 2015). Because of several studies (Hale \& Guan, 2015; Hewitt et al., 2018; Hinkley, Carson, Kalomakaefu, \& Brown, 2017; Lauricella, Wartella, \& Rideout, 2015; Sanders, Parent, Forehand, Sullivan, \& Jones, 2016) suggesting the use of ICT should be considered because it interferes with sleep and concentration in carrying out daily routines. Limiting screen time will have a good effect on student performance (Salomon \& Ben-David Kolikant, 2016). Another study concluded that by providing a safe web for children. Children's website is a great web that combines education (Putra et al., 2018) and entertainment (Misirli \& Odabaşi, 2009). In addition, in order to be effective and directed at how students become optimally helped in the use of ICT in the learning process, the teacher needs to understand the importance of scaffolding and carry out the right scaffolding process for students (Rahman, Abdurrahman, Kadaryanto, \& Rusminto, 2015; Nurulsari, Abdurrahman, \& Suyatna, 2017).

\section{Conclusion}

The "ICT Child Friendly" textbooks proved to be valid, practical and effective after being applied to prospective teacher students in early childhood education programs. The developed textbook is able to improve ICT professional competence in prospective teacher students which can be integrated in all aspects, namely the cognitive, affective, psychomotor domains. The benefits of this development can also be felt by early childhood, where children can construct their knowledge based on their experiences through learning using ICT that is appropriate, safe, and healthy 
to be held by PG-PAUD teacher candidates who have ICT professional competence. The effects of early childhood education teacher education, ICT can provide ICT stimulation that is appropriate for early childhood to develop optimally.

\section{Acknowledgements}

Thank you to the Sriwijaya University Community Service and Research Institute for providing research funding support with the title "Development of" Child Friendly ICT "Textbooks in developing professional competencies of UNSRI PG-PAUD Students. Acknowledgments are also given to the Rabbani and Matheriyah PAUD Institutions who assisted in providing information on various ICT components in PAUD institutions. Thank you to all UNSRI PG-PAUD students involved in this research. Finally, thanks to Rahmi Ramadhani, M.Pd and Rofiqul Umam, PhD who have helped in completing this research.

\section{Biodata of the Authors}

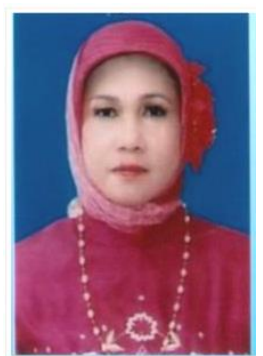

Dr. Sri Sumarni, M.Pd. Her research focuses on teacher behavior in managing children's emotions, learning mathematics in elementary school, politeness in language as the implementation of character-based education in PAUD in Palembang, an application of character-based politeness in learning devices in PAUD in Palembang. Affiliation: Department of Early Childhood Education, Universitas Sriwijaya, Simpang, Lorong Tembesu, Palembang, Indonesia.

E-mail: sri sumarni@fkip.unsri.ac.id / yik59unsri@yahoo.co.id

Phone: (+62)81383309035

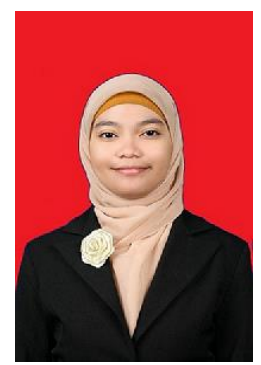

Rahmi Ramadhani, M.Pd was born in Medan, North Sumatera, Indonesia. She holds M.Pd (Magister of Education) in the Mathematics Education from State University of Medan in 2015. She is a lecturer in the Computer Engineering Department, Faculty of Informatics and Computer Engineering, Universitas Potensi Utama, Medan, North Sumatera, Indonesia. Her research focuses on mathematics education, Problem-Based Learning, Blended Learning, ICT in teaching and learning, problem solving ability, STEM education and ethno-mathematics. E-mail: rahmiramadhani3@gmail.com

Phone: (+62)81262900365. ORCID Number: 000-0002-8049-7234

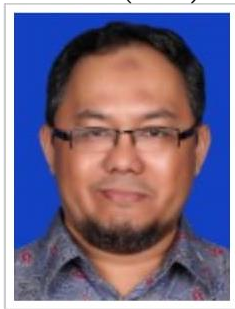

Yoppy Sazaki, M.T was born in Bandung, West Java, Indonesia. He holds M.T (Magister of Engineering) in Bandung Institute of Technology, Indonesia. He is a lecturer in the Management of Informatics, Faculty of Informatics and Computer Engineering, Universitas Sriwijaya, South Sumatera, Indonesia. E-mail: yoppysazaki@gmail.com

Phone: (+62)81321499985 

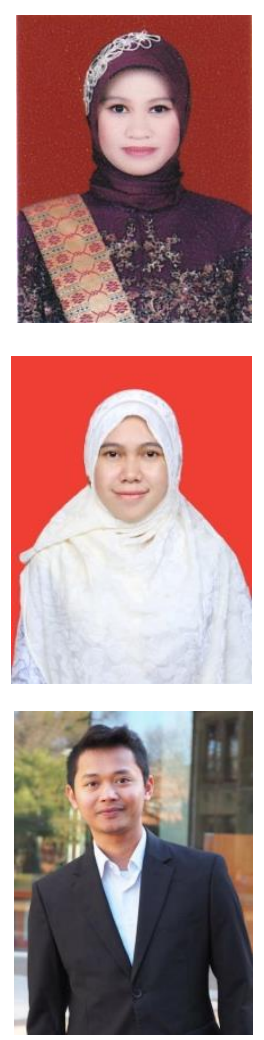

Ruri Tria Astika, M.Pd was born in Palembang, South Sumatera, Indonesia. The research focuses on elementary school children, thematic education, learning models, learning videos. Affiliation: Pascasarjana Universitas Negeri Jakarta, Khusus Ibu kota Jakarta 13220, Indonesia.

E-mail: ruritriaastika@yahoo.com

Phone: (+62)89633383768

Dr. Windi Dwi Andika, M.Pd. Her research focuses on early childhood education, teacher education science, early childhood games, early childhood teaching materials for students, e-learning media for early childhood students. Affiliation: Department of Early Childhood Education, Universitas Sriwijaya, Simpang, Lorong Tembesu, Palembang, Indonesia.

E-mail: dwiandika892014@gmail.com

Phone: (+62)82177354747

Andika Eko Prasetiyo, M.A. He holds master of Apllied Linguistics degree in theschool of humanities and social sciences, University of Melbourne, Australia in 2018. His research focuses on education, second language teaching, and language testing. Affiliation: School of humanities and social sciences, University of Melbourne.

E-mail: andikaekop@gmail.com

Phone: (+62)82134000746

\section{References}

Abdurrahman, A., Nurulsari, N., Maulina, H., \& Ariyani, F. (2019). Design and Validation of Inquiry-based STEM Learning Strategy as a Powerful Alternative Solution to Facilitate Gift Students Facing 21st Century Challenging. Journal for the Education of Gifted Young Scientists, 7(1), 33-56. https://doi.org/10.17478/jegys.513308

Abdurrahman, Saregar, A., \& Umam, R. (2018). Assessment Toward The Quantum Physics Concept Mastery Of The Prospective Physics Teachers. Jurnal Pendidikan IP A Indonesia, 7(1), 34-40. https://doi.org/10.15294/jpii.v6i2.7239

Aldoobie, N. (2015). ADDIE Model Analysis Phase. American International Journal of Contemporary Research, 5.6, 68-72.

Andini, M., \& Yunianta, T. N. H. (2018). The Development of Borad game "The Adventure Of Algebra" in The Senior High School Mathematics Learning. Al-jabar: Jurnal Pendidikan Matematika, 9(2), 95-109. https://doi.org/10.24042/ajpm.v9i2.3424

Aoki, K. (2010). The Use of ICT and e-Learning in higher education in Japan. World Academy of Science, Engineering and Technology, 66(6), 868-872.

Aslan, A., \& Zhu, C. (2015). Pre-Service Teachers' Perceptions of ICT Integration in Teacher Education in Turkey. TOJET: The Turkish Online Journal of Educational Technology, 14(3).

Deb Roy, S. (2015). Application of ICTs in Teaching-Learning Process. International Research Journal of Interdisciplinary \& Multidisciplinary Studies (IRJIMS) A Peer-Reviewed Monthly Research Journal, 1(7), 788711.

Diani, R., Herliantari, H., Irwandani, I., Saregar, A., \& Umam, R. (2019). The Effectiviness of SSCS Learning Model: Its Impact on the Students' Creative Problem-Solving Ability 
on the Concept of Substance Pressure. Jurnal Penelitian Fisika Dan Aplikasinya (JPFA), 9(1). https://doi.org/http://dx.doi.org/10.26740/jpfa.v9n1.p\%25p

Diani, R., Irwandani, I., Al-Hijrah, A.-H., Yetri, Y., Fujiani, D., Hartati, N. S., \& Umam, R. (2019). Physics Learning through Active Learning Based Interactive Conceptual Instructions (ALBICI) to Improve Critical Thinking Ability. Jurnal Penelitian Dan Pembelajaran IPA, 5(1), 48. https://doi.org/10.30870/jppi.v5i1.3469

Drigas, A., Kokkalia, G., \& Lytras, M. D. (2015). ICT and collaborative co-learning in preschool children who face memory difficulties. Computers in Human Behavior, 51, 645651. https://doi.org/10.1016/j.chb.2015.01.019

Ehsanipour, T., \& Gomez Zaccarelli, F. (2017). Exploring Coaching for Powerful Technology Use in Education.

Ghavifekr, S., Afshari, M., \& Salleh, A. (2012). Management Strategies for E-Learning System as the Core Component of Systemic Change: A Qualitative Analysis. Life Science Journal, 9(3), 1097-8135.

Ghavifekr, S., \& Rosdy, W. A. W. (2015). Teaching and learning with technology: Effectiveness of ICT integration in schools. International Journal of Research in Education and Science (IJRES), 1(2), 175-191.

Habibi, B., Hartinah, S., Umam, R., Syazali, M., Lestari, F., Abdurrahman, A., \& Jauhariyah, D. (2019). Factor Determinants of Teacher Professionalism as Development of Student Learning Education at School of SMK PGRI in Tegal City, Indonesia. Journal of Gifted Education and Creativity, 6(2), 125-134.

Hale, L., \& Guan, S. (2015). Screen time and sleep among school-aged children and adolescents: A systematic literature review. Sleep Medicine Reviews, 21, 50-58. https://doi.org/10.1016/j.smrv.2014.07.007

Hartinah, S., Sholikhakh, R. A., Umam, R., Syazali, M., Andriani, S., Mujib, ... Lestari, F. (2019). Application Auto-play Media Studio (AMS) 8 for Learning Me-dia of Logaritm Function. International Journal of Engineering \& Technology, 8(2), In Press. https://doi.org/10.14419/ijet.v7i4.27914

Hartinah, S., Suharso, P., Umam, R., Syazali, M., Lestari, B. D., Roslina, R., \& Jermsittiparsert, K. (2019). Teacher's performance management: The role of principal's leadership, work environment and motivation in Tegal City, Indonesia. Management Science Letters, 9(14), $1-$ 12. https://doi.org/10.5267/j.msl.2019.7.038

Hewitt, L., Benjamin-Neelon, S. E., Carson, V., Stanley, R. M., Janssen, I., \& Okely, A. D. (2018). Child care centre adherence to infant physical activity and screen time recommendations in Australia, Canada and the United States: An observational study. Infant Behavior and Development, 50(November 2017), 88-97. https://doi.org/10.1016/j.infbeh.2017.11.008

Hinkley, T., Carson, V., Kalomakaefu, K., \& Brown, H. (2017). What mums think matters: A mediating model of maternal perceptions of the impact of screen time on preschoolers' actual screen time. Preventive Medicine Reports, 6, 339-345. https://doi.org/10.1016/j.pmedr.2017.04.015

Kasayanond, A., Umam, R., \& Jermsittiparsert, K. (2019). Environmental Sustainability and its Growth in Malaysia by Elaborating the Green Economy and Environmental Efficiency. International Journal of Energy Economics and Policy, 9(5), 465-473. https://doi.org/https://doi.org/10.32479/ijeep.8310

Khoiriah, Jalmo, T., \& Abdurrahman. (2016). The effect of multimedia-based teaching materials in science toward students' cognitive improvement. Jurnal Pendidikan IPA Indonesia, 5(1), 75-82. https://doi.org/10.15294/jpii.v5i1.5793

Kirti., Mann, P., \& Gupta, R. (2014). ICT Competencies of Teachers-A Review. Journal of International Academic Research for Multidisciplinary, 2(4), 781-786. 
Komala Sari, F., Syazali, M., \& Farida. (2016). Pengembangan Media Pembelajaran (Modul) berbantuan Geogebra Pokok Bahasan Turunan. Jurnal Pendidikan Matematika, 7(2), 135151.

Kusumawati, R., \& Nayazik, A. (2018). Developing Mathematics Learning Strategy Module Based on Journal Review. Al-Jabar: Jurnal Pendidikan Matematika, 9(2), 111-120. https://doi.org/https://doi.org/10.24042/ajpm.v9i2.3110

Lauricella, A. R., Wartella, E., \& Rideout, V. J. (2015). Young children's screen time: The complex role of parent and child factors. Journal of Applied Developmental Psychology, 36, $11-$ 17. https://doi.org/10.1016/j.appdev.2014.12.001

Lecluijze, I., Penders, B., Feron, F. J. M., \& Horstman, K. (2015). Co-production of ICT and children at risk: The introduction of the Child Index in Dutch child welfare. Children and Youth Services Review, 56, 161-168. https://doi.org/10.1016/j.childyouth.2015.07.003

Lestari, F., Saryantono, B., Syazali, M., Saregar, A., Jauhariyah, D., \& Umam, R. (2019). Cooperative Learning Application with the Method of Network Tree Concept Map : Based on Japanese Learning System Approach. Journal for the Education of Gifted Young Scientists, 7(1), 15-32. https://doi.org/10.17478/jegys.471466

Maskur, R., Syazali, M., \& Utami, L. F. (2019). Islamic-Nuanced Calculus Module with OpenEnded Approach in Real Number System Material. Journal of Physics: Conference Series, 1155(1). https://doi.org/10.1088/1742-6596/1155/1/012081

Maulidi, I., Apriliani, V., \& Syazali, M. (2019). Fungsi Zeta Riemann Genap Menggunakan Bilangan Bernoulli. Desimal: Jurnal Matematika, 2(1), 43-47. https://doi.org/10.24042/djm.v2i1.3589

Mertala, P. (2017). Wag the $\operatorname{dog}-$ The nature and foundations of preschool educators' positive ICT pedagogical beliefs. Computers in Human Behavior, 69, 197-206. https://doi.org/10.1016/j.chb.2016.12.037

Misirli, Z. A., \& Odabaşi, H. F. (2009). Web sites for children. Procedia - Social and Behavioral Sciences, 1(1), 1183-1186. https://doi.org/10.1016/j.sbspro.2009.01.213

Mostafa, J., Hashemi, S. A., Sosahabi, P., \& Berahman, M. (2017). The role of ICT in learning-teaching process. World Scientific News, 72, 680-691.

Nisa, L. C. (2012). Pemanfaatan Teknologi Informasi untuk Pengembangan Kemampuan Berhitung Anak Usia Dini. SAWWA, 7(2).

Nurulsari, N., Abdurrahman, \& Suyatna, A. (2017). Development of soft scaffolding strategy to improve student's creative thinking ability in physics. Journal of Physics: Conference Series, 909(1). https://doi.org/10.1088/1742-6596/909/1/012053

Ozdilek, Z., \& Robeck, E. (2009). Operational priorities of instructional designers analyzed within the steps of the Addie instructional design model. Procedia Social and Behavioral Sciences, 1, 2046-2050. https://doi.org/10.1016/j.sbspro.2009.01.359

Peter Kayode, O., Bukola Olaronke, K., \& Kayode, P. (2014). Perceived Importance of ICT in Preparing Early Childhood Education Teachers for The New Generation Children. International Journal of Evaluation and Research in Education (IJERE), 3(2), 119-124.

Putra, F., Nur Kholifah, I. Y., Subali, B., \& Rusilowati, A. (2018). 5E-Learning Cycle Strategy: Increasing Conceptual Understanding and Learning Motivation. Jurnal Ilmiah Pendidikean Fisika Al-Biruni, 7(2), 171. https://doi.org/10.24042/jipfalbiruni.v7i2.2898

Rahman, B., Abdurrahman, A., Kadaryanto, B., \& Rusminto, N. E. (2015). Teacher-based scaffolding as a teacher professional development program in Indonesia. Australian Journal of Teacher Education, 40(11), 66-78. https://doi.org/10.14221/ajte.2015v40n11.4

Ramadhani, R., Umam, R., Abdurrahman, A., \& Syazali, M. (2019). The Effect Of FlippedProblem Based Learning Model Integrated With LMS-Google Classroom For Senior High School Students. Journal for the Education of Gifted Young, 7(2), 137 - 158. https://doi.org/https://doi.org/10.17478/jegys.548350 
Relmasira, S. C., \& Thrupp, R.-M. (2016). Preservice Teachers on Teaching with and About ICT: An Indonesian Study. Scholaria, 6(3), 163-172.

Rufaidah, E., AtIrsyadi, K. A., Saregar, A., \& Umam, R. (2018). The Effect of HALAL Label to Increase Domestic and International Tourism : Case Study In Lombok, Indonesia. International Journal of Management and Business Research, 8(4), 29-36.

Sagala, R., Umam, R., Thahir, A., Saregar, A., \& Wardani, I. (2019). The Effectiveness of STEM-Based on GenderDifferences: The Impact of PhysicsConcept Understanding. European Journal of Educational Research, 8(3), 753-763. https://doi.org/http://doi.org/10.12973/eu-jer.8.3.753

Salomon, A., \& Ben-David Kolikant, Y. (2016). High-school students' perceptions of the effects of non-academic usage of ICT on their academic achievements. Computers in Human Behavior, 64, 143-151. https://doi.org/10.1016/j.chb.2016.06.024

Samsudin, A., Suhandi, A., Rusdiana, D., Kaniawati, I., \& COŞTU, B. (2016). Investigating the effectiveness of an active learning based-interactive conceptual instruction (ALBICI) on electric field concep. Asia-Pacific Forum on Science Learning and Teaching, 17(1).

Sanders, W., Parent, J., Forehand, R., Sullivan, A. D. W., \& Jones, D. J. (2016). Parental perceptions of technology and technology-focused parenting: Associations with youth screen time. Journal of Applied Developmental Psychology, 44, 28-38. https://doi.org/10.1016/j.appdev.2016.02.005

Syahrir, S., Syazali, M., Masykur, R., Amrulloh, M. A., Sada, H. J., \& Listiani, B. (2018). Calculus Module for Derivative Application Materials with an Islamic Contextual Teaching and Learning Approach. IOP Conference Series: Journal of Physics, 1155. https://doi.org/10.1088/1742-6596/1155/1/012079

Syazali, M. (2015). Pengaruh Model Pembelajaran Creative Problem Solving Berbantuan Maple II Terhadap Kemampuan Pemecahan Masalah Matematis. Al-Jabar: Jurnal Pendidikan Matematika, 6(1), 91-98. https://doi.org/https://doi.org/10.24042/ajpm.v6i1.58

Syazali, M., Putra, F. G., Rinaldi, A., Utami, L. F., Widayanti, Jermsittiparsert, K., \& Umam, R. (2019). Partial correlation analysis using multiple linear regression: Impact on business environment of digital marketing interest in the era of industrial revolution 4.0. Management Science Letters, 9, In Press. https://doi.org/10.5267/j.msl.2019.6.005

Syazali, M., Sari, N. R., Sukawati, S., Sari, W. R., Pertiwi, S. D., Putra, A., \& Putra, F. G. (2019). Islamic-Nuanced Linear Algebra Module with Problem-Based Learning Approach for Linear Equation System Material. Journal of Physics: Conference Series, 1155(1). https://doi.org/10.1088/1742-6596/1155/1/012097

Vitanova, V., Atanasova-Pachemska, T., Iliev, D., \& Pachemska, S. (2015). Factors Affecting the Development of ICT Competencies of Teachers in Primary Schools. Procedia - Social and Behavioral Sciences, 191, 1087-1094. https://doi.org/10.1016/j.sbspro.2015.04.344

Vrasidas, C., \& Nicosia, C. (2001). Integrating Technology in Teaching and Teacher Education: Implications for Policy and Curriculum Reform. https://doi.org/10.1080/0952398011004194

Widayanti, Abdurrahman, A., \& Suyatna, A. (2019). Future Physics Learning Materials Based on STEM Education: Analysis of Teachers and Students Perceptions. Journal of Physics: Conference Series, 1155(1). https://doi.org/10.1088/1742-6596/1155/1/012021

Xiong, X. B., \& Lim, C. P. (2015). Curriculum Leadership and the Development of ICT in Education Competencies of Pre-service Teachers in South China. Asia-Pacific Education Researcher, 24(3), 515-524. https://doi.org/10.1007/s40299-015-0238-1 